Case Report

\title{
Malaria and Human Immunodeficiency Virus Infection
}

\author{
Brig SR Mehta, VSM*, Sqn Ldr AJ Swamy+, Maj J Muthukrishnan, SM", Col AK Malviya**
}

MJAFI 2004; 60 : 184-185

Key Words : HIV infection; Malaria

\section{Introduction}

A $\mathrm{n}$ association between malaria and human immunodeficiency virus (HIV) infection, common infections in the tropical countries, was expected in theory but had not been convincingly shown in practice till recently. A recent report from sub Saharan Africa demonstrating an increased frequency of clinical malaria and level of parasitemia in HIV 1 infected patients is an alarming one [1]. We describe a case from our country with HIV 1 infection and severe falciparum and vivax parasitaemia, which was successfully treated with chloroquine, sulfadoxine-pyrimethamine and primaquine.

\section{Case Report}

A 30 year old uneducated male was admitted to our hospital with complaints of moderate grade fever of 2 weeks duration. There was associated history of loss of appetite and significant weight loss. He denied respiratory or abdominal complaints, any skin rash or joint pains.

He gave history of numerous unprotected exposures to commercial sex workers and one episode of grouped painful penile ulcers about 3 days following the exposure. He denied past history suggestive of tuberculosis.

On examination, he was febrile with a temperature of $100.6^{\circ} \mathrm{F}$, pulse $106 / \mathrm{min}, \mathrm{BP} 130 / 80 \mathrm{mmHg}$ and respiratory rate of $18 / \mathrm{min}$. He had pallor, significant bilateral cervical, axillary and epitrochlear lymphadenopathy and hypopigmented scaly non-pruritic macular lesions over trunk and back (pityriasis versicolor).

Abdominal examination revealed firm, non-tender hepatomegaly (palpable $3 \mathrm{~cm}$ ) and splenomegaly (palpable 3 $\mathrm{cm}$ ) with no ascites. Clinical examination of the external genitalia did not reveal any abnormality. Other system examination was unremarkable.

Investigations revealed $\mathrm{Hb} 10 \mathrm{~g} \%$, ESR $36 \mathrm{~mm}-1^{\text {st }}$ hour, normal total and differential leukocyte counts, platelet count of $1,99,000 / \mathrm{mm}^{3}$. Quantitative buffy coat (QBC) was positive for malarial parasite. Peripheral blood smear showed numerous BT and MT trophozoites per high power field (parasitemia $=2 \%$ ). Metabolic parameters were within normal limits. He tested positive for HIV1 by ELISA, done twice by different test kits. The CD4 count was 280/ul and viral load assay could not be done due to technical constraints. Ultrasonographic abdomen examination revealed enlarged liver (span $16 \mathrm{~cm}$ ), spleen (span $13.5 \mathrm{~cm}$ ), with no ascites, mesenteric or retroperitoneal lymph nodes. Widal test was negative, VDRL was non-reactor and chest X-ray was normal. All biochemical parameters were within normal limits.

A diagnosis of HIV infection with mixed malarial infection was made and the patient was treated with oral chloroquine in standard doses for three days sulfadoxine-pyrimethamine three tablets stat and primaquine $7.5 \mathrm{mg}$ twice a day, for five days. He became afebrile 48 hours after starting treatment and remained so during the follow up period of 28 days. The parasitemia was $1 \%$ on day 2 , and the slide was negative for malarial parasite on days 3, 7 and 28 .

\section{Discussion}

Any interaction between malaria and HIV could be of immense public health significance. Plasmodium falciparum stimulates release of IL-6 and tumour necrosis factor alpha (TNF- $\alpha$ ) and the complications of severe falciparum malaria are mostly due to release of these cytokines. Increased levels of these cytokines have also been shown to stimulate HIV1 replication, thus increasing the HIV levels in these patients [2]. HIV1 proviral loads are significantly higher in patients with malaria than those without and remain higher for at least 4 weeks after treatment [3]. Thus malaria could cause faster progression of HIV1 disease.

One study has shown a significantly higher prevalence of symptomless malarial parasitemia in HIV positive adults in rural Tanzania and higher mortality due to malaria in HIV1 positive adults [4]. In our patient too, the symptoms were mild despite heavy parasite load. Higher parasitemia has been reported in HIV infected pregnant women in Malawi and postnatal infant mortality rate was higher if the mother had both infections than either one alone [5,6,7].

In a large study carried out in Uganda, HIV1 infection has been found to increase frequency of clinical malaria and parasite density with tendency to greater parasitemia

"Consultant and Head, Department of Medicine, Armed Forces Medical College, Pune - 411 040, ${ }^{+}$Graded Specialist (Medicine), 12 Air

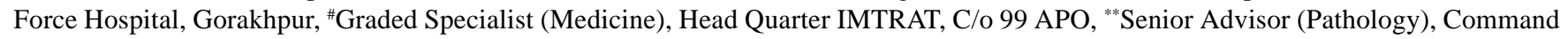
Hospital (Central Command), Lucknow. 
with advancing immunosuppression [1]. In other studies, though higher mortality due to malaria was not recorded, morbidity was definitely higher in HIV positive adults $[8,9]$. Chemoprophylaxis for malaria is less effective in HIV-positive than HIV negative pregnant women [10]. Thus, HIV coinfection alters all the aspects of malarial infection.

Sophisticated investigations like HIV 1 proviral loads, IL-6 and TNF alpha levels (which could not be carried out by us due to non availability) will be needed in future studies to determine the exact interaction between these two diseases. We also need to determine the impact of HIV infection on malarial chemoprophylaxis, specific effect of HIV infection on immunity against malaria and whether protection against malaria can slow the progression of HIV disease. The results of these studies will go a long way in prolonging the life of HIV patients as well as decreasing the mortality and morbidity due to malaria.

\section{References}

1. Whitworth J, Morgan D, Quigley M, Smith A. Effect of HIV1 and increasing immunosuppression on malarial parasitemia and clinical episodes in adults in rural Uganda : a cohort study. Lancet 2000;356:1051-6.

2. Xiao L, Owen SM, Rudolph DL, Lal RB, Lal A A. Plasmodium falciparum antigen-induced human immunodeficiency virus type- 1 replication is mediated through induction of tumor necrosis factor alpha. J Infect Dis 1998;177:437-45.

3. Hoffman IF, Jere CS, Taylor TE. The effect of $P$ falciparum malaria on HIV1 RNA plasma concentration. AIDS 1999;13:487-94.

4. Atzori C, Bruno A, Chichino G. HIV1 and parasitic infections in rural Tanzania. Ann Trop Med Parasitol 1993;87:585-93.

5. Steketee RW, Wirima JJ, Slutsker L, Breman JG, Heymann DL. Compatibility of treatment groups and risk factors for parasitemia at the first antenatal clinic in a study of malaria treatment and prevention in pregnancy in rural Malawi. Am J Trop Med Hyg 1996;55(1):17-23.

6. Steketee RW, Wirima JJ, Bloland PB. Impairment of a pregnant woman's acquired ability to limit Plasmodium falciparum by infection with human immunodeficiency virus type-1. Am J Trop Med Hyg 1996;55(1):42-9.

7. Steketee RW, Wirima JJ, Slutsker L. Malarial parasite infection during pregnancy and at delivery in mother, placenta and newborn : efficacy of chloroquine and mefloquine in rural Malawi. Am J Trop Med Hyg 1996;55(1):24-32.

8. Leaver RJ, Haile Z, Watters DA. HIV and cerebral malaria. Trans R Soc Trop Med Hyg 1990;84:201-3.

9. Niyongabo T, Deloron P, Aubury P. Prognostic indicators in adult cerebral malaria : A study in Burundi, an area of high prevalence of HIV infection. Acta Trop 1994;65:299-305.

10. Parise ME, Ayisi JG, Nahlen BL. Efficacy of SulfadoxinePyrimethamine for prevention of placental malaria in an area of Kenya with a high prevalence of malaria and human immunodeficiency virus infection. Am J Trop Med Hyg 1998;59:813-22.

\title{
ATTENTION ADVERTISERS
}

\author{
Rates of advertisements in Medical Journal Armed Forces India :

$\begin{array}{llll} & \text { Black \& White } & \text { Colour } & \text { Size } \\ \text { Full page (per issue) } & \text { Rs. 5000/- } & \text { Rs. 10000/- } & 25 \times 18 \mathrm{cms} \\ \text { Half page (per issue) } & \text { Rs. 3000/- } & \text { Rs. 6000/- } & 18 \times 12 \mathrm{cms} \\ & \text { (Positive for advertisement to be supplied by client) } \\ \text { Inserts (two pages) } & \text { Rs. 5000/- per insert (Black and White / Colour) } \\ & \text { (Printed inserts to be supplied by client) }\end{array}$

Address for Correspondence

EDITOR-IN-CHIEF

MEDICAL JOURNAL ARMED FORCES INDIA

C/o ARMED FORCES MEDICAL COLLEGE, PUNE - 411040. 